\title{
Topicalization, CLLD and the Left Periphery*
}

\author{
Liliane Haegeman \\ UMR 8258 Silex du CNRS
}

\begin{abstract}
Starting from a consideration of the internal make-up of adverbial clauses this paper shows that the widespread assumption that fronted arguments in English and CLLD constituents in Romance occupy the same position leads to a number of problems. I will conclude that the position occupied by English topicalized arguments differs from that of the CLLD topics in Romance. In particular, English topics occupy a higher position in the left periphery. The final part of the paper compares three proposals for the lower topic position in Romance.
\end{abstract}

\section{Topicalization in the Left Periphery}

In much recent literature on the left periphery inspired by Rizzi's seminal paper (1997), a point that has often gone relatively unquestioned is that crosslinguistically fronted topics occupy a designated position, the specifier of TopP. While admitting that there are differences in the way the topic is related to the host clause, Rizzi (1997) for instance, assumes that CL(itic)L(eft)D topics in Romance as well as fronted topics in English occupy Spec,TopP (also, for instance, Grewendorf 2002; Grohmann 2003; Platzack (2004), but see among others Benincà 2001; Benincà \& Poletto 2001; Frascarelli \& Hinterhölzl 2003; Lopez 2003; and Pereltsvaig 2004 for different views). Implicit in some proposals is also an assumption that the interpretation of fronted topics in English is not significantly different form that of fronted CLLD elements in the relevant languages. Delfitto (2002: 61) says: 'topics are interpreted in essentially the same way in English topicalization and Italian CLLD'. The conflation of the two types of fronted arguments arises probably because in many of the relevant papers authors either mainly look at English type topicalization or concentrate on CLLD and the two are not often systematically confronted. In this paper I want to highlight some differences in position between English topicalized arguments and CLLD arguments in Romance. The paper is organised as follows: Section 1 introduces the idea that English topicalization is a root phenomenon, section 2 discusses the syntax of adverbial clauses. Sections 3 and 4 show how embedded clauses may differ with respect to the composition of their left periphery: notably it is proposed that the CP of 'central' adverbial clauses, factive complements, subject clauses and infinitival clauses is structurally reduced and lacks the projections that licence topicalization. Section 5 deals with CLLD in Romance and shows that 
it has a wider distribution than topicalization in English, occurring precisely in the domains associated with a reduced CP. Section 6 postulates a lower position in the Romance left periphery which can host CLLD constituents. The section examines a number of proposals for locating this position in the left periphery. Section 7 discusses a complication with respect to conditional clauses containing CLLD constituents in Romance. Section 8 is a summary of the paper.

\subsection{Root Phenomena}

In a rich literature, going back to the 1970s, it has been acknowledged that there exists a range of syntactic phenomena whose application is restricted to root clauses and embedded clauses with root properties. English topicalization is taken to be one of these phenomena (Andersson 1975; Davison 1979; Emonds 1970, 2004; Green 1976; Haegeman 1984a,b, 1991, 2002a; Heycock 2002; Hooper \& Thompson 1973; Maki et al 1999; Rutherford 1970). With respect to defining the domain of application of topicalization and other main clause phenomena, Hooper \& Thompson (1973) argue that such phenomena are apparently related to 'asserted clauses'. They also point out that the relevant restriction cannot be syntactically represented, or if it could be, that such syntactic representation would not be explanatory:

As a positive environment we can say that [root] transformations operate only on Ss that are asserted. ...some transformations are sensitive to more than just syntactic configurations. It does not seem possible to define the domain of an RT in terms of syntactic structures in any general way. However, ..., even if it were possible to define in syntactic terms the conditions under which RTs can apply, ... the question of why these transformations can apply in certain syntactic environments and not others would still be unanswered. (Hooper \& Thompson 1973: 495, italics mine)

\subsection{Accounting for the Restriction}

It may be true that at the time that Hooper and Thompson were writing, no syntactic account for the restricted distribution of main clause phenomena was available, but note that the authors themselves do give a clear indication as to what the syntactic distinction should rest on when they say: 
Though RTs may apply in some complements that are full sentences introduced by the complementiser that, they may never apply in any complements that are reduced clauses. By reduced clauses we mean infinitives, gerunds, and subjunctive clauses, i.e. those complement types which have uninflected verbs. (Hooper \& Thompson 1973: 484-5, italics mine). ${ }^{1}$

At an intuitive level, we can reinterpret this to mean that root phenomena are licensed in domains with somewhat 'more functional structure', and that domains lacking that particular layer of structure will not allow root phenomena. A similar intuition is expressed by Larson \& Sawada (to appear) and by McCloskey (2004). In the first part of the paper I try to make this hypothesis more precise, using a modified version of Rizzi's split CP. I will start by examining argument fronting in adverbial clauses.

\section{Adverbial Clauses and Root Phenomena}

\subsection{Topicalization in Adverbial Clauses}

\subsubsection{English}

In English, we need to distinguish argument fronting from local adjunct fronting (Haegeman 2003a), a contrast which is not always explicitly addressed. While fronted arguments are typically restricted to root clauses or embedded clauses with root properties, fronted adjuncts are not subject to this restriction. $^{2}$

(1) a. *If these exams you don't pass you won't get the degree.

b. If next week you cannot get hold of me, try again later.

(2) a. *While her book Mary was writing this time last year, her children were staying with her mother.

b. While around this time last year Mary was writing her book, her children were staying with her mother.

\footnotetext{
*This paper was presented in various forms at, among others, the Workshop on Dislocated Elements in Discourse: Syntactic, Semantic, and Pragmatic Perspectives, 28-30 November 2003 ZAS, Berlin and the Georgetown University Round Table. Thanks to the audiences at both conferences for comments. Thanks also to Luis Lopez, Philip Miller, Nicola Munaro, Josep Quer, Luigi Rizzi, and Anna Roussou for judgements. Thanks to Paola Beninca, Valentina Bianchi, Luis Lopez, Cecilia Poletto, and Ben Shaer for comments on the paper. Needless to say they cannot be held for the way I have used their comments.

${ }^{1}$ Cf. Emonds 2004: 8.

${ }^{2}$ As signalled by McCloskey (2004), not all temporal clauses allow adjunct fronting.
} 
(3) a. *When her regular column she began to write for the Times, I thought she would be OK.

b. When last month she began to write a regular column for the Times, I thought she would be OK.

The differences between argument fronting and adjunct fronting in adverbial clauses are not immediately compatible with the analysis offered by Rizzi (1997), in which fronted arguments move to the specifier of TopP and fronted adjuncts are TopP adjoined. If both types of fronting involve the same projection TopP, then it is not clear how one can be ruled out while the other is grammatical. Haegeman $(2003 \mathrm{a}, \mathrm{b})$ proposes that, as suggested by Rizzi himself (1997: see his notes 26, 30 and 32), some fronted adjuncts need not be adjoined to TopP. Specifically, temporal adverbs may also be somewhat lower in the left periphery.

However, argument fronting is (marginally) possible in adverbial clauses with root like properties. (4) provides some examples: (4a) is from the literature, (4b-e) are attested examples, and (4f-h) are constructed examples.

(4) a. His face not many admired, while his character still fewer felt they could praise.

(Quirk et al 1985: 1378)

b. I think we have more or less solved the problem for donkeys here, because those we haven't got, we know about.

(Guardian, G2, 18.2.3, p. 3, col 2)

c. We don't look to his paintings for common place truths, though truths they contain none the less

(Guardian, G2, 18.2.3, p. 8, col 1)

d. Professor Head (Letters July 28) suggests the oath of allegiance implies commitment to monarchy as a system of government. It doesn't, though whether this will mollify him, I don't know.

(Guardian, 29.7.3, p. 17, col 5, letters to the editor,

Rev. Steve Parish. Warrington)

e. Naturally, my carrots, peas, beans, potatoes, lettuces and tomatoes have a taste beyond compare, although whether it is because they are organic or just mine I am not sure.

(Guardian 6.11.3. page 2, col 1)

f. If these problems we cannot solve, there are many others that we can tackle immediately.

g. If aphids we did not worry about, snails we did.

h. If anemonies you don't like, why not plant roses instead? 
I have proposed (Haegeman 2002a, 2003a, 2003b) that adverbial clauses that do not allow for fronted arguments are fully integrated in the host clause and are interpreted as modifying the event expressed in the associated clause. For instance, conditional clauses introduced by if refer to events/states of affairs that would be a sufficient cause for the event/state of affairs in the main clause to be realised; temporal clauses expressed by while express events/states of affairs that are the temporal frame for the event/state of affairs expressed in the main clause etc. I will label such adverbial clauses 'central adverbial clauses'.

On the other hand, 'peripheral' adverbial clauses do allow (to some extent) for argument fronting; they are less tightly connected to the host clause (see Haegeman (2002a, 2003b) for arguments) and serve to provide the discourse frame against which the proposition expressed in the host clause is evaluated. Adverbial while clauses of this type express a proposition which provides the privileged background that will enhance the relevance of the associated matrix clause; conditional if clauses express a premise which is entertained by the speaker and which serves as the privileged context for the processing of the main clause. In sum, the relevant adverbial clauses provide discourse backgrounds that serve as restrictors for processing, against such backgrounds the matrix clause yields particular contextual implicatures (see Haegeman 2002a, 2003b).

\subsubsection{Comparative Data}

The contrast in argument fronting between the two types of adverbial clauses is not confined to English. The contrast is also found in Japanese, in Korean (see Whitman 1989), in Gungbe, which I will illustrate below, and it has been reported for Chinese (Lu Peng 2003: 232-34). ${ }^{3}$

In Japanese $e^{4}, w a$ topicalization is not possible in central conditional clauses (Maki et al 1999) but it is licit in peripheral conditional clauses expressing a premise for the processing of the host clause.

\footnotetext{
${ }^{3}$ Lu Peng distinguishes an external topic from an internal one. The latter appears to the right of the subject and is arguably IP internal. It can occur in all types of adverbial clauses. The external topic is restricted to what would be peripheral adverbial clauses.

${ }^{4}$ Thanks to Hideki Maki (personal communication) for the Japanese data. See also Larson \& Sawada 2004: section 1.2.
} 
(5) a. *Mosi sono yoona zassi-wa, (anata-ga) yome- $b a$, if that like magazine-top (you-nom) read (CONDITIONAL)-if (anata-wa) yasai-ga sukini narimasu. (you-top) vegetable-nom like become

'If these magazines, you read, you will come to like vegetables'

b. Mosi sono yoona zassi-wa (anata-ga)

if that like magazine-top (you-nom)

sukide-nai (CONCLUSIVE )-naraba,

like-not-if

naze (anata-wa) (sorera-o) kai-tuzukerunodesu ka?

why (you-top) (them-acc) buy-continue, $Q$

'If such magazines, you don't like, why do you keep buying them?'

Observe that $b a$ in the central conditional clause is replaced by nara $b a$ in the peripheral conditional clause. With respect to nara Kuno says:

Concerning the conditional sentence pattern [S1 nara] S2: 'It is usually said that this pattern has a strong degree of assertion about the statement represented by S1'. (Kuno 1973: 168)

Korean shows a similar contrast between central conditionals, which do not allow topicalization, and peripheral ones, which do (see Whitman 1989):

(6) a. * $*_{\mathrm{i}}$ chayk-un (ku-ka) ilk-umyen/ilk-ess-umyen

$(\text { Korean })^{5}$ this book-Top (he-Nom) read-if / read-Past-if

ku-nun ama $\mathrm{ku}$ yenghwa-lul poko siphe hal kes-i-ta he-Top probably that movie-Acc see want will-Dec

'If this book, he reads/read, he will probably want to see that movie' (CENTRAL ADVERBIAL)

b. $k u$ chayk-un (ney-ka) cohaha-n-ta-myen way kukes-ul ca-ci

that book-Top (you-Nom) like-Pres-Dec-if why that-Acc buy-NMZ anh-ni?

not do- $Q$

'If that book, you like, why don't you buy it?'

(PERIPHERAL ADVERBIAL)

The contrast is also found in Gungbe (Enoch Aboh, personal communication): only $n i$ conditionals with echoic reading allow ya topicalization. (7) 'implies that speaker and hearer are not at the Procure, but in another bookshop where they have found a book that the hearer had seen at Procure and told the speaker about' (Enoch Aboh, personal communucation). ${ }^{6}$

\footnotetext{
${ }^{5}$ I thank Shin Sook Kim for the judgements.

${ }^{6}$ The resumptive pronoun $e(3 \mathrm{sg})$ is somewhere between a weak pronoun and a clitic (for discussion see Aboh 2004)
} 
(7) (*)Ni wema ehe lo ya, a mon e to Procure, xo e na mi. if book this Det Top 2sg see $3 \mathrm{sg}$ at Procure buy $3 \mathrm{sg}$ forme

\subsection{The Internal Structure of Adverbial Clauses}

In addition to differing with respect to the possibility of argument fronting, central and peripheral adverbial clauses display a series of other differences which can be reduced to one essential contrast: peripheral adverbial clauses allow for the encoding of illocutionary force, central adverbial clauses don't. As a result, peripheral adverbial clauses manifest a range of phenomena that involve anchoring to the speaker, these are absent from central adverbial clauses. I briefly go over some examples here.

\subsubsection{Speaker-oriented Epistemic Modals and Adverbial Clauses}

Peripheral adverbial clauses can, and central adverbial clauses cannot, contain expressions of epistemic modality:

(8) a. *Mary accepted the invitation without hesitation after John may have accepted it.

(based on Verstraete 2002: 149)

b.??John works best while his children are probably/might be asleep.

c. The ferry will be fairly cheap, while/whereas the plane may/ will probably be too expensive.

d. If Le Pen will probably win, Jospin must be disappointed. ${ }^{7}$

\footnotetext{
${ }^{7}$ The distinction between the two types of adverbial clauses is not always made, leading to a failure to identify the restrictions on the distribution of epistemic adverbials. For instance, in his discussion of the distribution of sentential adverbials, Nilsen (2004) points out that 'speaker oriented adverbs, such as evaluatives (fortunately), evidentials (evidently), and some modals (possibly) are degraded... in antecedents of conditionals' (2004: 811). In a footnote he then adds:
}

One can also find occurrences of probably in antecedents of conditionals which are not that bad.

[i] If Le Pen will probably win, Jospin must be disappointed.

I take the slipperiness of some these [sic] intuitions to be comparable to that found with relative adverb ordering. Consequently I will try to stick to phenomena for which intuitions are sharper. (2004: 811, n. 5)

Failure to distinguish the two types of adverbial clauses seems to be at the basis of the 'slippery intuitions'. Nilsen's problematic (i) is my (8d). It contains an instance of a peripheral conditional: the natural interpretation is that the conditional echoes a previous statement or proposition that is contextually salient. The fact that epistemic adverbials are licit in (i)/(8d) is then not unexpected. Such epistemic adverbials remain unacceptable in central adverbials. 
Epistemic modality is by definition anchored to the speaker: it expresses the speaker's stance concerning the likelihood of the state of affairs/event, which is anchored to speech time. Tenny (2000: 319) underlines the need for anchoring to speaker in relation to the highest adverbs in the Cinque (1999) hierarchy:

We cannot have a point of view without a sentient being to hold it. A speech act, of course, necesssarily involves the speaker as a participant, An evaluative expression, at the sentence level, reflects the point of view of the speaker. Evidentiality involves the speaker as a sentient perceiver, a proposition that is apparently true or false must be so to someone. Finally, epistemic modality, which addresses a state of knowledge of something, must involve a sentient mind that is in the state of knowing; at the sentential level it is the speaker who is represented as holding that knowledge. (Tenny 2000: 319)

Verstraete points out that even if 'epistemic modals can be morphologically associated with a past tense, ... this morphological marking does not express the speaker's past judgement. Either it is used for tentativeness,... or it occurs in a context of indirect or free indirect speech' (Verstraete 2002: 152, italics mine).

\subsubsection{Illocutionary Force}

The availability of epistemic modality in peripheral adverbial clauses and its absence in central adverbial clauses suggest that peripheral clauses can be anchored to the speaker in a way that central adverbial clauses cannot. This distinction is confirmed by the observation that peripheral adverbial clauses may contain indicators of illocutionary force, a point signalled by Declerck \& Reed (2001) for conditional clauses. Central adverbial clauses do not have independent illocutionary potential and they are integrated in the speech act conveyed by the associated clause.

When the Present Perspective System is used in the sub-clause [i.e. central conditional, LH], the speaker makes a single (but complex) prediction: she presents the contents of the two clauses as forming a unit. (Declerck \& Reed 2001: 131, italics mine)

When the Future Perspective System [i.e. peripheral conditional, lh] is used in both clauses [conditional and associated clause, lh], the speaker makes two independent predictions: there are, as it were, two illocutionary speech acts. (Declerck \& Reed 2001: 131, italics mine)

There are a number of empirical data illustrating this opposition.

\subsubsection{Echoic Effect in Conditional Clauses}

Declerck \& Reed (2001) signal that peripheral conditional clauses are echoic: 
closed P-clauses $[\approx$ peripheral conditional clauses, $\mathrm{LH}]$ are always echoic in one sense or another. They can echo straightforward statements about the actual world, or they can echo Q-propositions about a nonfactual world. However, the claim that closed P-propositions are echoic need not mean that they have to be echoes of actual utterances. They may also be echoes of an internal or mental proposition (thought) such as the interpretation of an experience, perception etc. (Declerck \& Reed 2001: 83)

Being 'echoic' implies a relation to the discourse, and one that is mediated by the speaker who 'echoes' a previous utterance/thought.

\subsubsection{Tags ( H\&T 1973: 471)}

Further evidence for the availability of illocutionary force in peripheral adverbial clauses and its absence in central adverbial clauses comes from the observation that the former may and that the latter may not have their own question tags associated with them. In (9a) the tag didn't she is related to the matrix clause; a tag hadn't they, which would have to be related to the adverbial clause, is not possible, as seen in (9b). Temporal while clauses show the same restrictions (10).

(9) a. Mary went back to college after/before her children had finished school, didn't she?

b. *Mary went back to college after/before her children had finished school, hadn't they?

(10) a. Bill took a degree at Oxford while his children were still very young, didn't he?

b. *Bill took a degree at Oxford while his children were still very young, weren't they?

The situation is different in peripheral adverbial clauses. Sentence-final contrastive while clauses will not normally be followed by a tag relating to the host clause. Such a tag would have to precede the contrastive while clause $(11 \mathrm{a}, \mathrm{b})$. On the other hand, a contrastive while clause may have its own tag (11c):

(11) a. *Bill took a degree at Oxford, while his daughter is studying at UCL, didn't he?

b. Bill took a degree at Oxford, didn't he, while his daughter is studying at UCL.

c. Bill took a degree at Oxford, while his daughter is studying at UCL, isn't she? 
(12) is an attested example with a question tag associated with a peripheral because clause:

(12) Henry III, for example, ruled for 56 years but his golden jubilee was a flop. 'Henry III?' they said, 'Erm, now which one's that then? 'Cos Henry $\mathrm{V}$ is Agincourt, isn't he...

(Guardian, 2.2.2., p. 8, col 2)

\subsubsection{Speech Act Adverbials}

Peripheral adverbial clauses may also contain adjuncts relating to the speech act, as illustrated by the following example:

(13) '[A referendum on a united Ireland ]...will be a 'good thing, because frankly they need to be taken down a peg and come down to earth and be a little bit more sober in their approach to things.'

(Guardian, 22.7.2, p. 4, col 4)

\subsubsection{4 (Rhetorical) Questions}

Among peripheral clauses, because and although are found to embed rhetorical questions.

(14) a. No one would have been too upset about her bad behaviour, because wasn't that what writers were put on earth to do?

(Observer, 20.8.2000 p. 27, col 8)

b. News about the anti-American demonstrations which had begun to appear in Berlin and other parts of Germany in the fortnight since the summit hadn't exactly helped sell what was supposed to be Michelle's greatest success. Although what did the mid-west care about Berlin?

(BNC, Verstraete 2002: 147)

The status of such examples may be debatable and some might consider them as a matter of usage rather than being grammatical in the strict sense (cf. Newmeyer 2003: 692). Still, the fact that such rhetorical questions are found at all in these adverbial clauses and that they are not found in the central ones, suggests that although clauses and because clauses can be associated by speakers with the type of illocutionary force typical of unembedded root clauses.

\subsubsection{Imperatives (Verstraete 2002: 146)}

Verstraete (2002: 146) signals that some peripheral adverbial clauses may also have imperative force markers. I refer to his work for discussion. 
(15) a. The students should have enough money, although remember we are expecting a drop in the department funding.

b. The fees should bring in more money, because remember we are expecting a drop in the department funding.

c.??The students should have enough money, while remember we are expecting a drop in the department funding.

\section{RT/MCP and the Internal Make-up of CP}

\section{1 'Structural Reduction'}

My proposal to account for the difference between central and peripheral adverbial clauses is inspired by Hooper and Thompson's own observation concerning the restricted distribution of root phenomena, which I have reproduced in the preceding section. They point out that root phenomena are generally excluded from structurally 'reduced' clauses. I propose that central adverbial clauses are reduced clauses, they are structurally deficient, while peripheral adverbial clauses can display the full clausal structure available in root clauses. More specifically, I locate this difference in the left periphery of the clause. I propose that the CP-domain of central adverbial clauses lacks the functional projection that guarantees anchoring to the speaker and which is projected in root clauses (and in clauses embedded under speech act verbs or propositional attitude verbs). The speaker-related projection, I contend, is available in peripheral adverbial clauses. The proposed structural distinction is semantically motivated. Central adverbial clauses are part of and modify the proposition with which they are associated, peripheral adverbial clauses express independent propositions, associated with illocutionary force, that serve as the immediate discourse background to the associated clause.

\subsection{RT/MCP and the Internal Make-up of CP}

\subsection{1 'Reduction' and Speaker-related Projections}

The structural distinction between the two types of adverbial clauses that is proposed is analogous to that postulated elsewhere to differentiate between types of complement clauses. Citing work by Benincà \& Poletto (2001), for instance, Grewendorf (2002: 53) refers to 'the idea that embedded clause vary as to which portions of the CP-layer may be projected, and that this has to do with the selectional properties of the matrix verb... it may be a property of 
non-bridge verbs that their complement does not project the whole CP-layer while bridge verbs select a complete CP-layer with all projections of the left periphery available' (for similar ideas, see also McCloskey 2004; Meinunger 2004, among others). My proposal is that the dual selectional behaviour of conjunctions is not restricted to those introducing complement clauses but extends to other subordinating conjunctions. For instance, while selects a different type of projection depending on its interpretation: central temporal while selects a reduced variant of $\mathrm{CP}$, peripheral, discourse related while selects the full $\mathrm{CP}$. In order to make this idea more precise, I will explore Rizzi's (1997) split CP.

\subsubsection{The Periphery of the Clause: the Split CP (Rizzi 1997)}

\subsubsection{Force versus Sub}

Various authors have proposed that the unitary CP-layer be replaced by a hierarchy of functional projections. (16a) is from Rizzi (1997).

(16) a. Force $>$ Topic $>$ Focus $>$ Fin $^{8}$

Following Bhatt \& Yoon (1992), Bennis (2000), Rizzi (1997: n. 6), Roussou (2000) and others, I propose to decompose the head labelled Force. Subordinating conjunctions are inserted in the position 'Sub'; Sub serves to subordinate the clause, to 'make it available for (categorial) selection independently of its force' (Rizzi 1997). A specific head, which I will label Force, guarantees anchoring to the speaker and is implicated in the licensing of, among other things, illocutionary force and epistemic modality. Roussou (2000) implements the idea that Rizzi's original functional head Force be split into two heads on the basis of data from Modern Greek.

For present purposes let us take the highest $\mathrm{C}$, realised by $p u$ in [17a], to have the properties of a subordinator: it connects the clause to some element of the higher clause (so that the former depends on the latter). [note omitted] Given its connecting properties we will simply refer to this head as C....

According to $[17 \mathrm{a}]$ there are three basic $\mathrm{C}$ positions each specified for different features. The higher $\mathrm{C}$ gives us 'subordination', the middle $\mathrm{C}$ clause-typing, and the lower C modality....Focus/Topic is situated between the two higher [heads] (Roussou 2000: 79)

[17] a. [C $p u\left[\right.$ Topic/ Focus $\left[\mathrm{COp}\right.$ oti/na/as $\left.\left.\left.\left[\mathrm{Neg}\left[\mathrm{CM} \theta a / \mathrm{t}_{\mathrm{na} / \mathrm{as}}[\mathrm{I} \mathrm{cl}+\mathrm{V} \ldots]\right]\right]\right]\right]\right]^{9}$

\footnotetext{
${ }^{8}$ Mainly on the basis of Romance data, Rizzi (1997) introduces a lower topic position to the right of Focus. This position is probably restricted to Romance (see section 5).

$9 P u$ : factive complements, oti: non factives. I have simplified Roussou's structures somewhat.
} 
In terms of my own labelling, Roussou's C-position corresponds to 'Sub', COp corresponds to 'Force' and CM corresponds to 'Fin'.

(17) b. [Sub $p u$ [Topic/ Focus [Force oti/ na/as [Neg [Fin $\left.\left.\left.\left.\left.\theta a / \mathrm{t}_{\mathrm{na} / \mathrm{as}}[\mathrm{I} \mathrm{cl}+\mathrm{V} \ldots]\right]\right]\right]\right]\right]$

Both central adverbial clauses and peripheral adverbial clauses contain the position Sub, which hosts the subordinating conjunction. Only peripheral adverbial clauses can contain Force. Root clauses obviously also contain the head Force. Central adverbial clauses refer to events/states of affairs, and lack manifestations of illocutionary force. We end up with the following functional hierarchies in the left periphery of finite clauses

(16) b. Central adverbial clause:

c. Peripheral adverbial clause: Sub

d. Root clause:
Sub

Top Focus Force Fin

Top Focus Force Fin

In anchoring the clause to the speaker, Force also anchors it to speech time. The independent encoding of temporal relations in a syntactic domain depends on anchoring to Speech time. ${ }^{10}$ Epistemic modality, which I take to be licensed by anchoring to speaker/speech time, similarly is licensed through the presence of the head Force. For a similar proposal relating epistemic modality and illocutionary Force I also refer to recent work by Bayer (2001: 14-15). ${ }^{11}$

\subsubsection{Topicalization and Force}

In a discussion of Bavarian emphatic topicalization, Bayer (2001) postulates a link between the presence of illocutionary Force and the availability of topicalization:

... this form of topicalization is the grammar's reflex of the speech act to be performed and is as such on a par with German constructions involving modal

\footnotetext{
${ }^{10}$ Conceivably, the dependency can also be stated the other way, in which case anchoring to speaker depends on Speech time. What is distinctive in peripheral adverbial clauses and what licences MCP would then be the syntactic encoding of Speech Time, with 'Force' perhaps relabelled ' $\mathrm{S}$ '. Such a position would entail the reworking of the claims made below but is not incompatible with the main argumentation of this paper. For instance, epistemic modality might be argued to depend on S. I hope to look into different alternative formulations in future work. See also Bianchi (2003), who proposes that the C domain encodes a logophoric center. Following Tenny's (2000) classification of adverbial adjunts one may also see Force as the encoding of Speaker deixis. Regardless of the label to designate the relevant head, the idea is that this head ensures the link-up of the clause to Speech time, Speaker deixis, Speaker point of view.

${ }^{11}$ In work on root phenomena in embedded clauses, Meinunger (2004) proposes that German embedded clauses displaying Verb Second are characterised by the presence of an assertion operator in the CP domain. This proposal is obviously compatible with postulating a Force projection in $\mathrm{CP}$.
} 
particles like aber, denn, doch, ja etc. Modal particles supply features which interact with other features such as $[\mathrm{WH}]$ yielding a wide range of illocutionary forces. Bayer 2001: 14-15)

....if emphatic topicalization belongs to the class of grammatical means of force projection in the sense of Rizzi (1997), its root clause property and strict left peripherality [in Bavarian] are not surprising.' (Bayer 2001: 14-15)

Putting things very roughly, (18a) with a fronted topic, would have the reading (18b): the speaker relates the topic to the clause that is predicated of this topic. In other words, topicalization is a kind of 'speech act' about the topic topic (cf. Reinhart, 1981: 64).

(18) a. This book, I don't like.

b. About this book, the speaker asserts that the speaker does not like it. $^{12}$

I assume that English topicalization depends on the presence of Force and that the language does not have any alternative way of relating a fronted topic to the associated clause. That topicalization is not available in central adverbial clauses in English is a consequence of the absence of the projection of the head Force. ${ }^{13}$ As we will see below, other languages do have alternative mechanisms for licensing fronted arguments in the left periphery.

The differentiation between two types of adverbial clauses in English is to be related to the more general distinction between clauses that express mere 'events/states of affairs' and those that are assertions associated directly with a speaker. In the next sections I review other embedded domains that can also be characterised in terms of a reduced CP-structure (see Hooper \& Thompson 1973).

\subsection{Factive Complements}

Melvold (1991) proposes to distinguish factive complements from non-factive complements in that the former are (definite) descriptions of individual events

\footnotetext{
${ }^{12}$ Though this needs to be worked out, I would like to explore the idea that topicalization structures like that in (18a) are the root/abstract counterparts to embedded patterns illustrated in (18c), in which a DP (Mr Bush) is related to the complement clause via a speech act verb (say) and the preposition of.

[i] Britany Clayton... said of Mr. Bush: 'He makes me nervous'.

(New York Times, 9.11.2, A16, col 5)

${ }^{13}$ Whitman (1989) postulates a link between topicalization and the availability of modal markers. If epistemic modality depends on Force (as suggested above), and if topicalization also depends on Force, this is expected. The restrictions could also be restated in terms of the alternative proposal briefly introduced in note 10: if topicalization depends on epistemic modality and if the latter is anchored to speech time, we predict topicalization will be excluded from non-root environments.
} 
while the latter are assertions, associated with truth value. In terms of the analysis proposed here, non-factive complements encode Force while factive complements lack Force (and TopP and FocP, the projections which are, by hypothesis, licensed by Force).

(19) a. Non-factive complements: that(Top)(Focus)Force Mod*Fin

b. Factive complements: that Mod*Fin

Hence factive complements are expected to resist topicalization, while nonfactive complements admit it:

(20) a. The inspector explained that each part he had examined very carefully. (Hooper \& Thompson, 1973: 474, their (48))

b. (\%)*John regrets that this book Mary read. ${ }^{14}$

(Maki et al 1999: 3, their (2c))

In my analysis, 'assertion' involves an extra layer of functional structure in the CP (see also Meinunger 2004), while presupposed complements lack that layer of the structure. My analysis contrasts rather sharply with Zubizarreta (2001), who says:

It is likely that factive predicates, which presuppose the truth of their propositional complement, contain an Ass(ertion) operator in its [sic, lh] CP. This operator is lexicalised by the complementizer, which explains why it must be obligatorily present [cf. John regrets *(that) Mary is bald]. Complements of propositional attitude verbs lack an Ass operator, therefore, their complementizer may be absent in some languages [cf. John thinks (that) Mary is bald]. (Zubizarreta 2001: 201).

Note that my analysis does not exclude that factive complements involve additional structure, but if they do, then it would be in terms of, for instance, being selected by a D-head, rather than there being additional $\mathrm{CP}$-internal structure.

\section{4 'Sentential Subjects' (Davies \& Dubinsky 1999, 2001; Koster 1978; Miller 2001)}

The observation that subject clauses resist topicalization (Hooper \& Thompson 1973: 476) can be interpreted as a consequence of their reduced structure:

(21)a. *That this book, Mary read thoroughly is true.

(Authier 1992: 332, his (17b))

\footnotetext{
${ }^{14}$ On factive verbs and semifactives see Hooper \& Thompson 1973: 480ff. For discussion of variable judgements on topicalization in factive complements I refer to Maki et al 1999.
} 
b. It is true that this book, he read thoroughly.

(Authier 1992: 333, his (18b))

This hypothesis would reconcile the claims that sentential subjects do not exist at all (Koster 1978) with proposals that they do exist (Davies \& Dubinsky 1999, 2001; Miller 2001). To the extent that sentential subjects can occupy the canonical subject position, my proposal is that they have a reduced $\mathrm{CP}$ (without Force). Sentential subjects with a full CP (with Force) could then be argued to occupy a peripheral position (Koster 1978; cf. Meinunger 2004). I hope to elaborate this conjecture in later work.

\section{CLLD is not a Root Phenomenon}

In the preceding sections, I interpret the non-occurrence of topicalization in English in specific clause types in terms of the impoverished structure of their CP-domain. If CLLD were interpretively and structurally identical to English topicalization (cf. Delfitto 2002; Rizzi 1997), we would predict that CLLD should be disallowed in the contexts disallowing topicalization in English, namely in central adverbial clauses, factive complements, sentential subjects and infinitival clauses. ${ }^{15}$ This prediction is not borne out at all. I first provide a survey of these contexts.

\subsection{Central Adverbial Clauses}

In (22)-(26), CLLD is apparently licensed in central adverbial clauses. It would appear that these clauses also refer to events/states of affairs and cannot be plausibly argued to differ interpretively from their English counterparts. ${ }^{16}$

\footnotetext{
${ }^{15}$ For a survey of the movement vs. base-generation debate and an analysis of CLLD in terms of the Big DP analysis see Cecchetto 2000.

${ }^{16}$ The data are complex, though. Carlo Cecchetto signals that though CLLD is possible in central adverbial clauses, it certainly is not as good as it would be in peripheral adverbial clauses. He gives the following, in which the (a) examples are peripheral adverbial clauses and the (b) examples contain central ones. The example of a temporal central adverbial clause with CLLD in (iiib) is particularly degraded.
}

(i) a. Se il dolce non lo porti, porta almeno il vino if the sweet non it bring-2SG, bring at least the wine 'If you are not bringing the sweet, then at least bring the wine.'

b. Se il dolce non lo porti, penseranno che sei mal educato if the sweet non it bring, think-FUT-3PL that be-2SG badly educated 'If you don't bring the sweet, they will think that you are not well educated.' 
(22) a. Se gli esami finali non $l i$ superi, non otterrai.

(It)

if the exams final non them pass-2SG, non obtain-FUT-2SG

il diploma

the diploma

'If you don't pass the final exams, you won't get the diploma.'

b. Se queste cose non le sai, non supererai l'esame. if these things non them know-2SG, not pass-FUT-2SG the exam 'If you don't know these things, you won't pass the exam.'

(23) a. Si aquest examen no l'aproves amb un cinc, if this exam no it pass-2SG with a five, perdràs el curs sencer.

lose-FUT-2SG the course entire

'If you don't pass this exam with a five, you'll lose the whole year.'

b. Quan aquesta cançó la vaig tornar a sentir al cap dels anys, when that song it returned to hear after some years, em vaig emocionar molt.

I was emotional very

'When I heard this song again after some years, I got really emotional.'

(ii) a. Se la pasta non la sai fare, è inutile che ci provi

if the pasta non it can-2SG make, is useless that it try-2SG

'If you cannot cook pasta, there's no point in trying.'

b. ?Se la pasta non la sai fare, penseranno che sei un cattivo cuoco if the pasta non it can-2SG make, think-FUT-3PL that be2SG a bad cook 'If you cannot cook pasta, they will think you're a bad cook.'

(iii) a. Mentre il pesce lo mangia, rifiuta di mangiare la carne while the fish it eat-3SG, refuse- $3 S G$ to eat the meat 'While he eats fish, he refuses to eat meat.'

b.??Mentre il pesce lo mangia, beve vino rosso While the fish it eat-3SG, drink-3SG wine red

'While he is eating fish he is drinking red wine.' 
(24) Si este examen no lo apruebas con un cinco, perderás if this exam no it finish-2SG with a five, lose-FUT-2SG el curso entero. ${ }^{17}$ the course entire 'If you don't pass this exam with a five, you'll lose the whole year.'

(25)\% Si ce livre-là tu le trouves à la Fnac, achète-le. ${ }^{18}$ if this book there you it find at the Fnac, buy-IMP it. 'If you it find this book at the FNAC, buy it.'
An afto to vivlio to vris
stin dhimotiki vivliothiki, ${ }^{19}$ if this the book it find-2SG in-the local library boris na to paraggilis stin kentriki vilviothiki could-2SG prt it order-2SG in-the central library 'If you find this book at the local library, then you can order it in the central library.'

\subsection{CLLD in Factive Complements ${ }^{20}$}

Factive complements resist topicalization in English (and in Japanese, cf. Maki et al 1999); they allow CLLD in Romance:

\footnotetext{
${ }^{17}$ Catalan and Spanish judgement thanks to Josep Quer (personal communication). However, as shown by the following quotation from Escobar (1997), judgements seem to vary. She says:

For Spanish, left-dislocated phrases with CLLD cannot appear embedded with subjunctive mood which otherwise seems to facilitate the most clear cases of embedding in Spanish:
}

(i) ??/* Ella prefiere que a Luis, el médico lo examine.

She prefers that a Luis the doctor him examines

...we may conclude that CLLD is a root phenomenon. (Escobar 1997: 248)

On the other hand, Luis Lopez (personal communication) indicates that to him (i) sounds perfect with a postverbal subject:

(ii) Ella prefiere que a Luis lo examine el medico (no el enfermero). she prefers that Acc Luis CL examine-SUBJ the doctor (not the nurse)

${ }^{18}$ See also Ashby 1988, Barnes 1985, Lambrecht 1981. There is considerable variation among informants

${ }^{19}$ Thanks to Anna Roussou for the MG data. See also Anagnostopoulou (1997: 160) for Modern Greek CLLD.

${ }^{20}$ Factive complements are often subjunctive in Romance. In English subjunctive complements also resist topicalization.

(i)*It's important that the book he study carefully. (H\&T 1973: 485, their (166))

For French subjunctives, see, among others, Hirschbühler 1997. 
(27) a. E' strano che questo problema gli studenti non is strange that this question the students non l'abbiano potuto risolvere. ${ }^{21}$ it have-SUBJ-3PL can-PART solve

b. Mi dispiace che questo problema gli studenti non me displeases that this problem the students non l'abbiano potuto risolvere. it have-SUBJ-3PL can-PART solve

c. Lamento que aquesta pregunta els meus estudiants no regret-1SG that this problem the my students no l'hagin contestat correctament. it have-3PL answered-PART correctly

d. És estrany que aquesta pregunta els meus estudiants no is strange that this question the my students no l'hagin contestat correctament. it have-3PL answered-PART correctly

e. C'est bizarre que ce texte-là personne ne le connaisse. (Fr) it is strange that that text-there no one ne it knows-SUBJ

f. J'ai beaucoup regretté que ce texte-là I have much regretted that that text there ils n' l'aient pas discuté they ne it have-SUBJ not discussed-PART

g. Lipithike pu tin diatrivi tu dhen tin ixan paraggili $(\mathrm{MG})^{22}$ resented-3SG that the thesis his not it had-3PL ordered stin vivliothiki in-the library

h. Ine parakseno pu afto to vivlio dhen to exoun is strange that this the book not it have-3PL stin vivliothiki. in-the library

\subsection{Sentential Subjects}

In Italian, sentential subjects also do not pose any particular problems for the licensing of CLLD. ${ }^{23}$

\footnotetext{
${ }^{21}$ CLLD is slightly more marked there with respect to bridge verb complements, comparable to CLLD with infinitives (Luigi Rizzi, personal communication).

${ }^{22}$ Thanks to Anna Roussou for the MG data.

${ }^{23}$ Thanks to Nicola Munaro and Luigi Rizzi for the judgements on these sentences.
} 
(28) a. Che questo problema, i professori non l'abbiano

(It) that this problem, the professors non it have-SUBJ-3PL potuto risolvere mi sembra improbabile. can PART solve me seems unlikely

b. Che questo problema, il governo non lo voglia that this problem, the government non it want-SUBJ-3SG discutere mi sembra probabile. discuss me seems unlikely

For Catalan and Spanish, the judgements are less clear: sentential subjects are marginal and more so with CLLD. But the informant I consulted did not consider them to be ungrammatical: ${ }^{24}$

(29) a. ?Que los profesores no hayan podido resolver that the professors not have can-PART solve este problema me parece improbable.

this problem me seems unlikely

b.??Que este problema los profesores no lo hayan podido (Sp) that this problem the professors no it have can-PART resolver me parece improbable. to solve me seems unlikely

c. ?Que el gobierno no quiera discutir este problema that the govenment no wants discuss this problem me parece probable.

me seems likely

d.??Que este problema el gobierno no lo quiera discutir (Sp) that this problem the govenment no it wants discuss me parece probable.

me seems likely

(30) a. ?Que els professors no hagin pogut resoldre aquest that the professors no have can-PART solve this problema em sembla improbable. problem me seems unlikely

b.??Que aquest problema els professors no l'hagin pogut that this problem the professors no it have can-PART resoldre em sembla improbable. solve me seems unlikely

\footnotetext{
${ }^{24}$ Judgements Josep Quer. Note that both (29a) and (29b) are acceptable for Luis Lopez.
} 
c. ?Que el govern no vulgui discutir aquest problema that the governmnent no wants discuss this problem em sembla probable.

me seems likely

d.??Que aquest problema el govern no el vulgui discutir that this problem the government no it wants discuss em sembla probable.

me seems likely

Though this suggests cross-linguistic differences which one would have to further examine, I will conclude from the data above that CLLD is at least more easily available in sentential subjects in Romance than topicalization would be in English sentential subjects, again showing CLLD is not subject to the same licensing requirements.

\subsection{CLLD in Infinitival Complements}

That CLLD has a wider distribution than topicalization and that it occurs in what Hooper and Thomson referred to as 'reduced' structures is also clear when we consider their 'reduced' contexts. Infinitival control complements resist topicalization in English:

(31) *I have decided your book to read.

On the other hand CLLD is (at least marginally) possible in Romance infinitival control clauses as shown by the following data from the literature.

(32) a. Gianni pensa, il tuo libro, [Fin di] conoscerlo bene.

Gianni thinks, the your book, di know-it well

(Rizzi 1997: 309)

b. Mi sembra, il tuo libro, [Fin di] conoscerlo bene. (Rizzi 1997: 309) me seems, the your book, di know-it well

c. Gianni sostiene, il tuo libro, [Fin di] conoscerlo bene. Gianni maintains, the your book, di know it well

(Bianchi 2001: 29, her (69c))

Significantly, though, raising complements disallow CLLD. I return to this presently.

(33) *?Gianni sembra, il tuo libro, conoscerlo bene.

Gianni seems the your book know-it well

With respect to French, there is speaker variation. Tellier gives the contrast in (34): 
(34) a. Je cherche, ton livre, à l'acheter d'occasion.

I seek-for your book à it buy second hand

(Tellier 2001: 356-7)

b. *Je cherche à, ton livre, l'acheter d'occasion.

I seek-for à your book it buy second hand

Rizzi comments: 'Speakers of French are reluctant to accept CLLD with infinitives. Nevertheless, a detectable contrast exists between control and raising (Ch. Laenzlinger p.c.):

(34) c.??Je pense, ton livre, pouvoir le comprendre.

I think, your book, can it understand.

d. *Marie semble, ton livre, pouvoir le comprendre.

Marie seems, your book, can it understand

(Rizzi 1997: 331, n. 24)

Spanish is more restrictive than Italian: ${ }^{25}$ Observe that there is no overt spellout of Fin in (35), which might suggest that there is less structure than in Italian, where $d i$ spells out Fin.

(35) a. *Juan piensa, tu libro, conocerlo bien

Juan thinks, your book, know-it well

b. *Me parece, tu libro, conocerlo bien

Me seems, your book, know-it well

c. *Juan sostiene tu libro conocerlo bien

Juan maintains your book know-it well

\subsection{CLLD in French Complex Inversion}

Further evidence to distinguish CLLD from topicalization is that in spoken French CLLD constituents may intervene between the constituent that triggers inversion and the inverted verb or auxiliary as discussed by Laenzlinger \& Musolino (1995):

(36) a. Où celivre (Jean) l'a-t-il acheté? where this book (John) it has -he bought

(Laenzlinger \& Musolino 1995: 83)

b. Où Jean ce livre l'a -t-il acheté? where John this book it has he bought

(Laenzlinger \& Musolino 1995: 83)

\footnotetext{
${ }^{25}$ Judgement from Enriqueta Perez Vazquez. As shown in note 17, there may be variation among speakers.
} 
Once again, fronted arguments cannot intervene between the trigger for inversion and the inverted auxiliary in English (see Haegeman 2000):

(36) c. Many of these proposals not only do I agree with, but they were included in the text.

d. *Not only do many of these things I agree with.

\subsection{Preliminary Conclusion}

The data discussed above suggest quite clearly that the CLLD constituent in the left periphery is to be found in environments that resist topicalization in English. In particular while topicalization in English can be related to the availability of anchoring to speaker (which I locate in the functional head labelled 'Force'), this is not a property of CLLD, which has a significantly wider distribution. These findings cast doubt on the assumption that topicalized arguments as well as CLLD constituents invariably target Spec,TopP. Some authors have indeed signalled that CLLD has a wider distribution than English topics. Cinque (1990), for instance, says:

[the] 'left-dislocated' phrase of CLLD [in Italian, LH] can occur at the front of virtually any subordinate clause type. Here again CLLD contrasts with LD, which typically occurs in root contexts and (to different degrees of marginality) in the complements of only a few classes of propositional attitude verbs (Cinque 1990: 58)

(See also Hirschbühler 1997: 62 for French.)

In the next section I will speculate on the difference between the Englishtype topicalization and CLLD.

\section{A Lower Topic Position in the Left Periphery}

\subsection{CLLD Topic is Higher than Preverbal Subject}

To account for the wider distribution of CLLD, one might propose that the dislocated DPs are IP-adjoined.

The topic in CLLD... may be adjoined to a root clause or an embedded clause. (Zubizarreta 1998: 187)

Zubizarreta (1998) also suggests that CLLD constituents may actually occupy Spec IP:

Spanish to some extent resembles some of the Germanic languages - specifically, Yiddish and Icelandic (references omitted).... Languages with a generalised TP may be said to allow a certain amount of feature syncretism. More precisely, in 
these languages a discourse-based functional feature, such as 'topic', 'focus', or 'emphasis', may combine with the feature $\mathrm{T}$ (ense), giving rise to the syncretic categories $\mathrm{T} /$ 'topic', $\mathrm{T} /$ 'focus', $\mathrm{T} /$ 'emphasis'. A topic, focused, or emphatic phrase may therefore be moved to [Spec,T] for feature-checking purposes ... This of course is possible only to the extent that the nominative subject can be licensed in these languages in some way other than via specifier-head agreement with $\mathrm{T}$. (Zubizarreta 1998: 100)

In work on German, Frey (2004) proposes that topics may be licensed in a medial position in the IP domain and Meinunger (2000) interprets Germanic scrambling as IP-internal topicalization. One might try to generalise their proposals to CLLD. However, though IP-internal fronted arguments with a topic reading may exist, this analysis does not apply to the left-dislocated DP in CLLD. Observe, for instance, that the CLLD constituent in central adverbial clauses precedes the subject. These data suggest that the CLLD constituent can at best be IP adjoined.

(37) a. Se queste cose Maria non le sa, non supererà if these things Maria non them knows, non pass-FUT-3SG l'esame the exam

b. Si aquest examen el Josep no l'aprova amb un cinc, if this exam the Josep no pass-3SG with a 5, perdrà el curs sencer. lose-FUT-3SG the year whole

c. Si este examen Juan no lo aprueba con un cinco, if this exam Juan no pass-3SG with a 5 , perderá el curso entero. miss-FUT-3SG the year whole

Moreover, in Italian control infinitives (cf. (32)), the dislocated DP constituent precedes $d i$ which Rizzi associated with the lowest head Fin of the CP domain. The dislocated constituent cannot follow $d i$. This means that an IP adjunction analysis cannot account for the distribution of the CLLD constituent.

(38)*Mi sembra, [Fin di] il tuo libro, conoscerlo bene. me seems di the your book know-it well

(Rizzi 1997: 309)

\subsection{A Lower TopP in the Periphery}

The discussion above leads to the conclusion on the one hand, that CLLD constituents are IP-external and on the other, that they do not depend on the presence of Force. One way of interpreting this is to propose that in addition to the higher topic position licensed by Force, there is a lower position for CLLD 
constituents. Some such proposals have been elaborated. I will discuss three of them here.

\subsubsection{Rizzi 2001}

In order to accommodate the distribution of left dislocated constituents and adjuncts in Italian, Rizzi (2001) postulates a recursive topic position below the Focus position, which can be preceded by fronted adverbial adjuncts. I refer to his paper for details.

(39) Rapidamente, $\mathrm{i}$ libri, li hanno rimessi a posto. quickly, the books, them have-3PL put-PART to place

(Rizzi 2001, his (49))

This leads him to propose the more articulated periphery in (40).

(40) Force Top* Int Top* Focus Mod* Top* Fin IP

$(\operatorname{Rizzi} 2001)^{26}$

Observe that lower topic is located immediately above Fin and that it is lower than Mod, the position for locally fronted adjuncts. Mod must also be available in central adverbial clauses, since these allow adjunct fronting (Haegeman 2003a). Reduced structures thus allow for the projection of the position Mod. Hence, we expect the lower topic position to be available in reduced structures. In particular, we predict that CLLD is licit in Control clauses, which are arguably reduced CPs with Fin still available, but that CLLD will not be available in Raising clauses which are arguably CP-less structures, lacking Fin altogether. The prediction is borne out as shown by Italian (32/3) and French (34d).

While CLLD is licit in central adverbial clauses, focalization is not possible. This suggests that the reduced CP-structure is indeed truncated above Mod.

(41) a. *Se GLI ESAMI FINALI non superi, non otterrai

If THE EXAMS FINAL non pass-2SG, non obtain-FUT-2SG

il diploma. ${ }^{27}$

the degree

${ }^{26}$ On the recursion of Top, see below. For the projection Int, see discussion in Rizzi's paper.

${ }^{27}$ The judgements are no different if the adverbial clauses occur sentence finally:

(i) a. *Non otterrai il diploma, se GLI ESAMI FINALI non superi.

b. *Non supererai l'esame, se QUESTE COSE non sai.

Thanks to Nicola Munaro for judgements on these examples. 
b. *Se QUESTE COSE non sai, non supererai

if THESE THINGS not know-2SG, non pass-FUT-2SG the il l'esame.

the exam

As expected, focalization also leads to a degradation in sentential subjects, where CLLD is possible (cf. (28) above). ${ }^{28}$

(42) a.?(?)Che QUESTO PROBLEMA i professori non that THIS PROBLEM the professors non abbiano potuto risolvere mi sembra improbabile. have-SUBJ-3PL can-PART solve me seems unlikely.

b.?(?)Che QUESTO PROBLEMA il governo non voglia that THIS PROBLEM the government non want-SUBJ-3SG discutere mi sembra probabile. discuss me seems likely.

Similarly, focalization leads to strong degradation in control complements: ${ }^{29}$

(43) a.?(?)Gianni pensa IL TUO LIBRO di conoscere bene, non il suo. Gianni thinks THE YOUR BOOK di know well, non the his

b. *Mi sembra IL TUO LIBRO di conoscere bene, non il suo. me seems THE YOUR BOOK to know well, non the his

If we postulate a lower position for licensing CLLD constituents in Romance, dominating FinP, and if we also assume that this position is not available in English, we can relate the difference in distribution to the proposals elaborated above for the structure of CP. English topicalization depends on the availability of the higher head Force; similarly Focus in the CP domain is anchored to Force. In Romance CLLD can also be licensed by an alternative mechanism. This suggestion entails that there should be some further interpretive differences between the two types of topics. I return to this point presently.

One prediction of Rizzi's hierarchy in (40) is that the 'lower topic' or the fronted adverbial adjunct should be able to follow a focalized constituent or an interrogative $w h$-constituent (assumed to occupy Spec,FocP). This prediction

${ }^{28}$ As expected, the degradation is far less when the clause is extraposed. (cf. (21) in the text).

(i) a. ?Mi sembra improbabile che QUESTO PROBLEMA i professori non abbiano potuto risolvere.

b. ?Mi sembra probabile che QUESTO PROBLEMA il governo non voglia discutere

${ }^{29}$ Thanks to Nicola Munaro for judgements. The apparently neat distinction between (43a) and $(43 b)$ remains unaccounted for. 
is not borne out. Concerning this problem for his analysis, Rizzi (2001:16) says the following:

Preposed adverbials can't naturally occur in a position lower than the Wh element either, a property plausibly related to the obligatory adjacency between the $W h$ element and the inflected verb, whatever its ultimate theoretical status ...:

[44] *Che cosa, rapidamente, hanno fatto? what, rapidly, did they do

A particularly clear indication of the peculiar distributional properties of preposed adverbs emerges with $W h$ elements not requiring inversion, such as perché in Italian ...): the preposed adverb can follow but cannot precede perché, while a topic can occur in both positions:

[45] a. Perché, improvvisamente, Gianni è tornato a casa? why, suddenly, Gianni went home

b. *Improvvisamente, perché Gianni è tornato a casa? suddenly, why Gianni went home

[46] a. Perché, il mio libro, Gianni lo ha portato via? why, my book, Gianni took it away

b. Il mio libro, perché Gianni lo ha portato via? my book, why Gianni took it away

\subsubsection{Benincà \& Poletto 2001}

An alternative lower topic position is elaborated in work by Benincà (2001) and by Benincà \& Poletto (2001), who propose that the left periphery be decomposed as in (47): ${ }^{30}$

(47) ForceP... Hanging topic... Left Dislocated Topic... Focus FinP

This hierarchy distinguishes between a higher (Hanging) Topic (HT) position and a lower Left Dislocated Topic. There is only one Hanging Topic per clause, while there may be multiple Left Dislocated (LD) Topics.

The LD position in (47) could be taken to correspond to the lower position occupied by CLLD constituents. This assumption correctly predicts that. multiple CLLD constituents are possible in Romance (48) (see Delfitto 2002):

(48) a.
the book
a Gianni, glielo daro
without doubt

senz'altro.

(Rizzi 1997: 290, his (21))

Multiple fronted arguments are also possible in central adverbial clauses. This is expected, if we assume that such arguments target the lower LD position, given that $\mathrm{LD}$ is recursive. ${ }^{31}$

\footnotetext{
${ }^{30}$ I have adjusted their hierarchy to enable easier comparison with Rizzi's hierarchy.
} 
(48) b. Se a Gianni questo libro non glielo mostro, if to Gianni this book non him-it show-1SG, sarà molto deluso.

be FUT-3SG very disappointed

c. Se a Maria di questo problema non gliene parleremo, if to Maria of this problem non her-of-it speak-FUT-1PL, non potrà aiutarci.

non can- FUT-3SG help-us

As there tends to be only one topic per clause in English (see Rizzi 1997), we do not equate the English topic position with Benincà \& Poletto's LD position. Rather we equate the English TopP with their HT position.

Unlike Rizzi's analysis referred to above, Benincà \& Poletto's hierarchy straightforwardly predicts that LD topics do not occur to the right of focalized constituents. However, their analysis raises a problem. If we adopt a truncation analysis for central adverbial clauses, sentential subjects, and infinitival clauses, then in order to allow for LD topics to occur in such reduced structures, these clauses would have to be truncated just under the hanging topic:

(47) b. reduced structure

\section{Left Dislocated Topic...Focus FinP}

c. full structure

ForceP... Hanging topic...Left Dislocated Topic...Focus FinP

In this view, Focus would have to remain available in reduced structures. This does not give the correct predictions: focalized constituents lead to ungrammaticality in reduced structures.

${ }^{31}$ Thanks to Nicola Munaro for the data. Observe that multiple topicalization is also possible in temporal adverbials:

(i) a. Quando a Gianni questo libro gliel'ho mostrato, ne è rimasto molto deluso.

when to Gianni this book him it have-1SG shown, of it be-3SG remained very

disappointed

b. Quando a Maria di questo problema gliene ho parlato,

when to Maria of this problem to her-of it have-1SG talked,

mi ha capita perfettamente.

me has-3SG understood perfectly

Larson \& Sawada (2004) point out that in some temporal adverbial clauses only one CLLD constituent is possible. This suggests that such temporal adverbial clauses impose some additional restriction. See also McCloskey 2004. 


\subsubsection{Frascarelli \& Hinterhölzl 2003}

In work on the interpretive and prosodic properties of topics, Frascarelli \& Hinterhölzl (2003) distinguish three types of topics, two of which are immediately relevant to our concerns.

- The ABOUTNESS TOPIC occupies the highest Topic position in the left periphery. Frascarelli \& Hinterhölzl say: "it is cognitively speaking important for such Topics to occur at the beginning of the sentence.' (cf. Lambrecht 1994: 194). ABOUTNESS Topics are located in a higher position with respect to $\mathrm{WH} / \mathrm{Focus}$ constituents.

- The Familiarity TOPIC occupies the lowest TopP projection. FAMILIAR Topics are located lower than $\mathrm{WH} /$ Focus constituents and they can be realized in either peripheries. ${ }^{32}$

The structure these authors propose for the left periphery is the following:
a. [AboutP [ContrP [FocP
[FamP [IP

In terms of the analysis elaborated here, the ABOUTNESS topic would be associated with an 'illocutionary act' licensed by Speech act/ Force in my own account. The FAMILIARITY topic is not dependent on Force and is licensed in a lower position.

\section{ABOUTNESS topics are unique:}

A sentence can only contain one ABOUTNESS Topic, while multiple FAMILIAR Topics are allowed (different elements can be part of background information). (Frascarelli \& Hinterhölzl 2003, handout p. 6, their (7))

The hierarchy postulated here is similar to that proposed by Rizzi (2001): the lower FAMILIARITY topic follows the focalized constituent. Again, assuming truncation above FamP for the reduced structures, we correctly predict that reduced clause types will allow FAMILIARITY topics though not focalized constituents nor ABOUTNESS topics. That multiple topics are possible in reduced clauses $(48 \mathrm{~b}, \mathrm{c})$ is also expected:
b. Reduced structures
Sub $[$ Famp $[$ IIP
c. Full embedded structures Sub [AboutP [ContrP $[$ FocP $[$ FamP $[$ IP

Again the non-occurrence of a FAMILIARITY topic with a higher focalized constituent remains to be accounted for. Perhaps one can invoke the adjacency constraint referred to by Rizzi (5.2.1).

\footnotetext{
${ }^{32}$ CONTRASTIVE topics are located between ABOUTNESS and FAMILIARITY. Lopez (2003) points out that Catalan CLLD arguments are contrastively stressed. Italian or Spanish CLLD arguments do not have to be contrastively stressed, on the other hand.
} 


\subsection{The Role of Fin}

The proposals discussed above distinguish at least two topic positions, the lower of which could be argued to survive in reduced clauses. This lower position can then be claimed to be targeted by CLLD topics in Romance, and to be unavailable for topics in English. The analysis raises the immediate question why the lower topic position is not available in English (and similar languages). ${ }^{33}$ I speculate that it is the feature content of Fin in Romance and in Modern Greek that licenses the lower topic position (cf. Lopez 2003, Grewendorf 2002 for proposals that involve Fin in topic licensing). This analysis gives a more prominent role to Fin in the left periphery. It is not clear to me at this point which property of Fin should be singled out for the licensing of the lower topic. Some properties of Fin that could be explored could be that it encodes Reference time (Reichenbach 1947; Hornstein 1990). In contrast, Speech time could then be related to 'Force'. A proposal along the same lines is that Fin encodes the 'Perspective point' (Bianchi \& Bertinetto 1996; Bianchi, Bertinetto \& Squartini 1995) (see also Boeckx 1998, 2001: 50, which links FinP and point of view). Adapting proposals by Bianchi (2003), one might also relate the $\mathrm{CP}$ domain strongly to the logophoric centre of the clause and propose that Fin encodes the 'Internal logophoric centre' (Bianchi 2003) while Force encodes the External logophoric centre in 'Force' (pace Bianchi 2003).

Inspired by Delfitto (2002), I assume that the relation between the CLLD constituent in the left periphery and the clitic in the IP domain is one of agreement and that no formal feature checking is required. Delfitto (2002) also proposes that multiple topics are possible in the case of CLLD (cf. (48)) precisely because no feature checking is involved. However, if the presence of the clitic as such were always sufficient to allow for multiple topics in CLLD structures, then one would expect Romance ABOUTNESS topics also to be recursive, contrary to Frascarelli \& Hinterhölzl's conclusions.

\section{A Final Problem: Pied-piping and Adverbial Clauses (Munaro 2004)}

There is one remaining problem for the account of CLLD elaborated here. As it stands the occurrence of CLLD is dependent on Fin and should not give rise to any of the illocutionary effects which I associate with the presence of Force.

\footnotetext{
${ }^{33}$ Note that the topic position postulated for small clauses ( Basilico 2003) would have to be interpreted differently. Perhaps in terms of the 'subject of predication' of Cardinaletti (1997, 2000) and of Haegeman (2002b).
} 
However, this does not seem correct. In a discussion of CLLD in conditional clauses in Italian, Munaro (2004) says:

The topicalization internal to the conditional antecedent is subject to restrictions; a constituent can be felicitously topicalized inside a conditional only when the ifclause precedes the main clause, that is, when it is itself a topic. (Munaro 2004)

The generalisation also applies to the other Romance languages examined here. The relevant data are given in (50):

(50) a. *Non supererai l'esame se questo non lo sai notn pass-FUT-2SG the exam if this non it know-2SG

(Munaro 2004)
b. *Perdràs el curs sencer, si aquest examen no l'aproves amb un cinc it pass-2SG with a five
c. *Perderás el curso entero, si este examen no lose-FUT-2SG the course entire if this exam no lo apruebas con un cinco.
it pass-2SG with a five
d. *Achète-le si ce livre-là tu le trouves à la Fnac. buy-IMP it if this book there you it find at the Fnac

One way of reconciling this observation with the account above is to propose (following Munaro 2004) the following:

1. Romance CLLD FAMILIARITY topics may target a lower landing site in the $\mathrm{CP}$ domain.

2. However, FAMILIARITY topics still require anchoring to the discourse. The low position the FAMILIARITY topics attain in the central adverbial clause is inadequate to fully license these topics because central adverbial clauses lack the projections to ensure anchoring to the discourse.

3. 'Pied piping' of adverbial clause to the topic projection of matrix $\mathrm{CP}$ makes up for internal deficiency of the central adverbial CP and guarantees licensing of (lower) topic.

A similar pied piping analysis has been proposed to account for emphatic topicalization in central adverbial clauses in Bavarian (Bayer 2001) and for the licensing of verb second patterns in complement clauses in German (Meinunger 2004). I hope to return to this issue in future work. 


\section{Summary}

In this paper I examine some differences between English topicalization and Romance (and Modern Greek) CLLD. English topicalization is essentially a root phenomenon: it is excluded from central adverbial clauses, factive complements, subject clauses and infinitival complements. CLLD is not subject to this restriction. I propose that English topicalization be related to assertive illocutionary force as encoded by the functional head Force in the left periphery. When the left periphery is structurally reduced, Force is not projected and topicalization is illicit.

The data suggest that the position occupied by CLLD complements is lower than FocP. CLLD does not depend on Force but is licensed through Fin. In structurally reduced clauses in which Force is not projected but in which Fin is projected, CLLD remains licit. The fact that focalization, unlike CLLD, is not available in the reduced structures suggests that this too depends on Force.

\section{References}

Aboh, Enoch. 2004. The Morphosyntax of Complement-Head Sequences : Clause Structure and Word Order Patterns in Kwa. Oxford University Press, New York.

Anagnostopoulou, Elena. 1997. Clitic Left Dislocation and Contrastive Left Dislocation. In Elena Anagnostopoulou, Henk van Riemsdijk \& Frans Zwarts, eds., Materials on Left Dislocation, John Benjamins, Amsterdam, pp. 151-192.

Andersson, Lars-Gunnar. 1975. Form and Function of Subordinate Clauses. Gothenburg Monographs on Linguistics 1. Department of Linguistics, University of Göteborg.

Ashby, William. 1988. The Syntax, Pragmatics, and Sociolinguistics of Left- and Rightdislocations in French. Lingua 75: 203-229.

Authier, J.-M. 1992. Iterated CPs and Embedded Topicalisation. Linguistic Inquiry 23: 329336.

Barnes, Betsy. 1985. Left Detachment in Spoken Standard French. John Benjamins, Amsterdam.

Basilico, David. 2003. On the Topic of Small Clauses. Linguistic Inquiry 34: 1-36.

Bayer, Josef. 2001. Asymmetry in Emphatic Topicalization. In Caroline Féry and Wolfgang Sternefeld, eds., Audiatur Vox Sapientiae, Studia Grammatica 52. Akademie Verlag, Berlin, pp. 15-47.

Benincà, Paola. 2001. The Position of Topic and Focus in the Left Periphery. In Guglielmo Cinque \& Giorgio Salvi, eds., Current Studies in Italian Linguistics Offered to Lorenzo Renzi. Foris, Dordrecht, pp. 39-64.

Benincà, Paola \& Cecilia Poletto. 2001. Topic, Focus and V2: Defining the CP Sublayers. Ms. University of Padova. Talk presented at the Siena Workshop on Cartography.

Bennis, Hans. 2000. On the Interpretation of Functional Categories. In Hans Bennis, Maarten Everaert, \& Eric Reuland eds., Interface Strategies. KNAW publications.

Bhatt R, and J. Yoon. 1992. On the Composition of Comp and Parameters of V-2. In D. Bates, ed. Proceedings of WCCFL 10. CSLI, Stanford, pp. 41-53.

Bianchi, Valentina. 2001. On Person Agreement. Ms., University of Pisa. 
Bianchi, Valentina. 2003. On Finiteness as Logophoric Anchoring. In Jacqueline Guéron and Liliane Tasmowski. Temps et Point de Vue/Tense and Point of View. Université Paris X, pp. 213-246.

Bianchi, Valentina, Pier Marco Bertinetto and Maria Squartini. 1995. Perspective Point and Textual Dynamics. In Pier Marco Bertineto, Valentina Bianchi, Mario. Squartini and James Higginbotham, eds., Temporal Reference: Aspect and Actionality, Vol 1: Semantic and Syntactic Perspectives. Rosenberg and Tellier, Turin, pp. 309-324.

Bianchi, Valentina and PierMarco Bertinetto. 1996. Temporal Adverbs and the Notion of Perspective Point. In Violetta Koseska-Toszewa and Danut Rytel-Kuc, eds., Semantyka a Konfrontacja Jezykowa. Warszawa Polska Akademia, Nauk, pp. 11-21.

Boeckx, Cedric. 1998. Raising in Romance. Ms., University of Connecticut. (Available at http://mitpress.mit.edu/celebration)

Boeckx, Cedric. 2001. On the Co-occurrence of Expletives and Definite Subjects in Germanic. In Werner Abraham \& Jan-Wouter Zwart, eds., Issues in Formal German(ic) Typology. John Benjamins, Amsterdam/New York, pp. 45-64.

Cardinaletti, Anna. 1997. Subjects and Clause Structure. In Liliane Haegeman, ed., The New Comparative Syntax. Longman, London, pp. 33-63.

Cardinaletti, Anna. 2000. Towards a Cartography of Subject Positions. Ms, University of Venice/SSLMIT, University of Bologna.

Cecchetto, Carlo 2000. Doubling Structures and Reconstruction Probus 12: 1-34.

Cinque, Guglielmo. 1990. Types of $A$ '-dependencies. MIT Press, Cambridge, MA.

Cinque, Guglielmo. 1999. Adverbs and Functional Heads. Oxford University Press, Oxford/New York.

Davies, William \& Stan Dubinsky. 1999. Sentential Subjects as Complex NPs: New Reasons for an Old Account of Subjacency. CLS 34.83-94.

Davies, William \& Stan Dubinsky 2001. Functional Architecture and the Distribution of Subject Properties. In Davies, William \& Stan Dubinsky, eds., Objects and other Subjects. Kluwer, Dordrecht, pp. 247-280.

Davison, Alice. 1979. Some Mysteries of Subordination. Studies in the Linguistic Sciences 9: 105-128.

Declerck, Renaat \& Susan Reed. 2001. Conditionals: A Comprehensive Empirical Analysis. Mouton de Gruyter, Berlin.

Delfitto, Dennis. 2002. On the Semantics of Pronominal Clitics and some of its Consequences. Catalan Journal of Linguistics 1: 41-69

Doherty, Monica. 1985. Epistemische Bedeuting. Akademie-Verlag, Berlin.

Emonds, Joseph. 1970. Root and Structure-preserving Transformations. Ph.D. diss., MIT, Cambridge, MA.

Emonds, Joseph. 2004. Unspecified Categories as the Key to Root Constructions. In David Adger, Cécile de Cat \& George Tsoulas, eds., Peripheries. Kluwer, Dordrecht, pp. 75120.

Escobar, L. 1997. Clitic Left Dislocation and other Relatives. In Elena Anagnostopolou, Henk van Riemsdijk and Frans Zwarts, eds., Materials on Left Dislocation. Benjamins, Amsterdam, pp. 233-274.

Frascarelli, Maria \& Roland Hinterhölzl. 2003. Types of Topics in German and Italian. Workshop on Information Structure and the Architecture of Grammar: A Typological Perspective, 1-2 February 2004.

Frey, Werner. 2004. A Medial Topic Position for German. Linguistische Berichte 198: 153190.

Green, Georgia. 1976. Main Clause Phenomena in Subordinate Clauses, Language 52 : 38297. 
Grewendorf, Günther. 2002. Left Dislocation as Movement. In Simon Mauck \& Jenny Mittelstaedt, eds., Georgetown University Working Papers in Theoretical Linguistics 2, pp. 31-81.

Grohmann, Kleanthes. 2003. Prolific Domains. Benjamins., Amsterdam.

Haegeman, Liliane. 1984a. Parasitic gaps and adverbial clauses. Journal of Linguistics 20: 229-232.

Haegeman, Liliane. 1984b. Pragmatic conditionals in English. Folia Linguistica 18: 485502.

Haegeman, Liliane. 1991. Parenthetical Adverbials: The Radical Orphanage Approach. In Shuji Chiba, Akira Ogawa, Yasuaki Fuiwara, Norio Yamada, Osamu Koma \& TakaoYagi, eds., Aspects of Modern English Linguistics: Papers Presented to Masatomo Ukaji on His 60th Birthday. Kaitakusha, Tokyo, pp. 232-53.

Haegeman, Liliane. 2000. Inversion, Non-adjacent inversion and Adjuncts in CP. In Paul Rowlett, ed., Transactions of the Philological Society, Special Number: Papers from the Salford Negation Conference. Vol. 98: 121-160.

Haegeman, Liliane. 2002a. Anchoring to Speaker, Adverbial Clauses and the Structure of CP. In Simon Mauck \& Jenny Mittelstaedt, eds., Georgetown University Working Papers in Theoretical Linguistics 2, pp. 117-180.

Haegeman, Liliane. 2002b. Sentence-Medial NP-adjuncts in English. Nordic Journal of Linguistics 25: 79-108.

Haegeman, Liliane 2003a.Notes on Long Adverbial Fronting in English and the Left Periphery. Linguistic Inquiry 34: 640-649.

Haegeman, Liliane. 2003b. Speculations on Adverbial Fronting and the Left Periphery. In Jacqueline Guéron and Liliane Tasmowski, eds., Temps et Point de Vue/Tense and Point of View. Université Paris X, pp. 329-365.

Heycock, Caroline. 2002. Embedded Root Phenomena. Ms., University of Edinburgh.

Hirschbühler, Paul. 1997. On the Source of Lefthand NPs in French. In Elena Anagnostopoulou, Henk van Riemsdijk and Frans Zwarts eds., Materials on Left Dislocation. Benjamins, Amsterdam, 55-66.

Hooper, John, and Sandra. Thompson. 1973. On the Applicability of Root Transformations. Linguistic Inquiry 4: 465-97.

Hornstein, Norbert. 1990. As Time Goes By. MIT Press, Cambridge, MA.

Iatridou, Sabine and Tony Kroch 1992. The Licensing of CP Recursion and Its Relevance to the Germanic Verb-Second Phenomenon. Working Papers in Scandinavian Syntax 50: 124.

Koster, Jan. 1978. Why Subject Sentences Don't Exist. In S. Jay Keyser, ed., Recent Transformational Studies in European Languages. MIT Press, Cambridge, MA, pp. 5364.

Kuno, Susumo. 1973. The Structure of the Japanese Language. MIT Press, Cambridge, MA.

Laenzlinger, Christopher \& Julien Musolino. 1995. (Complex) Inversion and Triggers. GenGenP 3: 77-96.

Lambrecht, Knud. 1981. Topic, Antitopic and Verb Agreement in Non-standard French. Benjamins, Amsterdam.

Lambrecht, Knud. 1994. Information Structure and Sentence Form: Topic, Focus and the Mental Representations of Discourse Referents. Cambridge University Press Cambridge.

Larson, Richard. K. and Miyuki Sawada. To appear. Presupposition \& Root Transforms in Adjunct Clauses. In Keir Moulton \& Matthew Wolf, eds., Proceedings of NELS 34. GLSA, University of Massachusetts, Amherst. 
Lopez, Luis. 2002. Toward a Grammar without TopP and FocP. In Simon Mauck \& Jenny Mittelstaedt, eds., Georgetown University Working Papers in Theoretical Linguistics, Vol. 2: 181-209.

Lopez, Luis. 2003. Steps for a Well-adjusted Dislocation. Studia Linguistica 57: 193-232.

Lu, Peng. 2003. La Subordination Adverbiale en Chinois Contemporain. Ph.D. diss., Paris 7.

Maki, Hideki, Lizanne Kaiser \& Masao Ochi. 1999. Embedded Topicalization in English and Japanese. Lingua 109: 1-14.

McCloskey, Jim. 2004. Questions in a Local English. Paper presented at Georgetown University Round Table.

Melvold, J. 1991. Factivity and Definiteness. More Papers on Wh-movement: MIT Working Papers in Linguistics.

Meinunger, Andre. 2000. Syntactic Aspects of Topic and Comment. Benjamins, Amsterdam.

Meinunger, Andre. 2004. Verb Second in German(ic) and Mood Selection in Romance. Paper presented at the Workshop on Clause Typing and the Left Periphery. Georgetown University Round Table.

Miller, Philip. 2001. Discourse Constraints on (Non) Extraposition from Subject In English. Linguistics 39: 683-701.

Munaro, Nicola. 2004. Computational Puzzles of Conditional Clause Preposing. In R. Delmonte, \& A. M. Di Sciullo, eds., UG and External Systems. John Benjamins, Amsterdam/Philadelphia.

Newmeyer, Frederick. 2003. Grammar is Grammar and Usage is Usage. Language 79: 682707.

Nilsen, Øystein. 2004. Domains for Adverbs. In Artemis Alexiadou, ed., Adverbs across Frameworks: Lingua 114: 809-847.

Pereltsvaig, Asya. 2004. Topic and Focus as Linear Notions: Evidence from Italian and Russian. In Dirk Bury, Karen Froud, Richard Horsey and Kriszta Szendroï, eds., Focus and the Interaction between Syntax and Pragmatics: Lingua 114: 325-344.

Platzack, Christer. 2004, Cross-linguistic Word Order Variation at the Left Periphery: The Case of Object First Main Clauses. In David Adger, Cécile de Cat \& George Tsoulas, eds., Peripheries. Kluwer, Dordrecht, pp. 191-210.

Quirk, Randolph, Joseph Greenbaum, Geoffrey Leech \& Jan Svartvik. 1985. A Comprehensive Grammar of the English Language. Longman, London.

Reichenbach, Hans. 1947. Elements of Symbolic Logic. Free Press, New York.

Reinhart, Tanya 1981. Pragmatics and Linguistics: An Analysis of Sentence Topics. Philosophica 27: 53-93.

Rizzi, Luigi. 1997. The Fine Structure of the Left Periphery. In Liliane Haegeman, ed, Elements of Grammar. Kluwer, Dordrecht, pp. 281-337.

Rizzi, Luigi. 2001. Locality and Left Periphery. Ms. University of Siena.

Roussou, Anna. 2000. On the Left Periphery: Modal Particles and Complementisers. Journal of Greek Linguistics 1: 65-94.

Rutherford, William. 1970. Some Observations Concerning Subordinate Clauses in English. Language 46: 97-115.

Tellier, Christine. 2001. On some distinctive properties of parasitic gaps in French. In Peter Culicover \& Paul Postal, eds, Parasitic Gaps. MIT Press, Cambridge, MA, pp. 341-367.

Tenny, Carol. 2000. Core Events and Adverbial Modification. In Carol Tenny \& James Pustejovsky, eds., Events as Grammatical Objects. CSLI, Stnford, pp. 285-334.

Verstraete, Jean-Christophe. 2002. Interpersonal Grammar and Clause Combining in English. Ph.D. diss, University of Leuven.

Whitman, John. 1989. Topic, Modality, and IP Structure. In Susumo Kuno et al., eds., Proceedings of the Third Harvard Workshop on Korean Linguistics. Hanshin, Seoul. 
Zubizarreta, Maria Luisa. 1998. Prosody, Focus and Word Order. MIT Press, Cambridge, MA.

Zubizarreta, Maria Luisa 2001. Constraints on Preverbal Subjects in Romance Interrogatives. In Aafke Hulk \& Jean-Yves Pollock, eds., Subject Inversion in Romance and the Theory of Universal Grammar. Oxford University Press, New York, pp. 183-204. 